\title{
Orthopedic Implications of the Corona Mortis: A Case Report
}

\author{
Implicaciones Ortopédicas de la Corona Mortis: Reporte de un Caso
}

\author{
Marcio A. Babinski ${ }^{1,2}$; Claudio Pena Gonçalves ${ }^{2}$; Daniel Ramallo ${ }^{3}$; \\ Lucas A. S. Pires ${ }^{1}$ \& Rodrigo M. P. Fernandes ${ }^{1,4}$
}

BABINSKI, M. A.; GONÇALVES, C. P.; RAMALLO, D.; PIRES, L. A. S. \& FERNANDES, R. M. P. Orthopedic implications of the corona mortis: A case report. Int. J. Morphol., 36(1):31-34, 2018.

SUMMARY: Corona mortis is classified as a connection between the inferior epigastric and obturator vessels over the superior pubic ramus. Its incidence varies among different studies. The corona mortis is an extremely important anatomical variation as it can be injured in a great number of procedures. Moreover, it can also be injured during pelvic or acetabular fractures. A male cadaver fixed in a $10 \%$ formalin solution had its pelvic region dissected and an arterial corona mortis was observed on its right side. The left hemipelvis presented no variations whatsoever. This vessel was measured with the aid of a digital caliper. We aim to report this variation and address - from an orthopedic point of view - the clinical and surgical significance of the corona mortis.

KEY WORDS: Anatomical variations; Corona mortis; Orthopedic Procedures; Acetabulum; Pelvic bones.

\section{INTRODUCTION}

Corona mortis (CM) is defined as an arterial or venous anastomosis between anastomotic branches of the obturator artery (OA) and the interior epigastric artery (IEA) over the superior pubic ramus (SPR) (Baena et al., 2015; Al Talalwah, 2016; Tajra et al., 2016; Wada et al., 2017).

The prevalence of this connection is motif of debate in the literature due to discrepancies of rates in different studies (Stavropoulou-Deli \& Anagnostopoulou, 2013; Pellegrino et al., 2014; Al Talalwah; Tajra et al.; Wada et al.).

Despite that, the CM possesses a surgical and clinical interest as it is susceptible to iatrogenic injuries during a great deal of surgical procedures (hernia repairs and orthopedic access to treat acetabular fractures for instance). Moreover, there is great difficulty in achieving hemostasis when the CM is injured during surgery (Davey \& Santore, 1999; Theodorides et al., 2011; GarridoGomez et al., 2012; Palacio \& Albareda, 2014; Yang et al., 2015; Wada et al.).
In addition, it can be ruptured in acetabular and SPR fractures, thus, leading more complication to a patient's health (Theodorides et al.; Garrido-Gomez et al.; Palacio \& Albareda).

This present work aims to describe a case of an arterial and venous CM and discuss its surgical and clinical aspects.

\section{CASE REPORT}

During regular dissection in the anatomical laboratory of the Fluminense Federal University, a male cadaver fixated in a $10 \%$ formalin solution showed an arterial and venous $\mathrm{CM}$ on its right hemipelvis (Fig. 1). There were no variations on its left side. Measurements were taken with a digital caliper.

The vessels were carefully dissected. The length (origin $\mathrm{x}$ pubic symphysis) of the corona mortis vessels was $54 \mathrm{~mm}$ and it possessed $3 \mathrm{~mm}$ of caliber.

\footnotetext{
${ }^{1}$ Department of Morphology, Biomedical Institute, Fluminense Federal University, Niterói, Rio de Janeiro, Brazil.

${ }^{2}$ Traumatology and Orthopedic Service, Salgado Filho Hospital, Rio de Janeiro, Brazil.

${ }^{3}$ Orthopedics Service, Copa D'Or Hospital, Rio de Janeiro, Brazil.

${ }^{4}$ Orthopedics Service, Americas Medical Group, Rio de Janeiro, Brazil.
} 


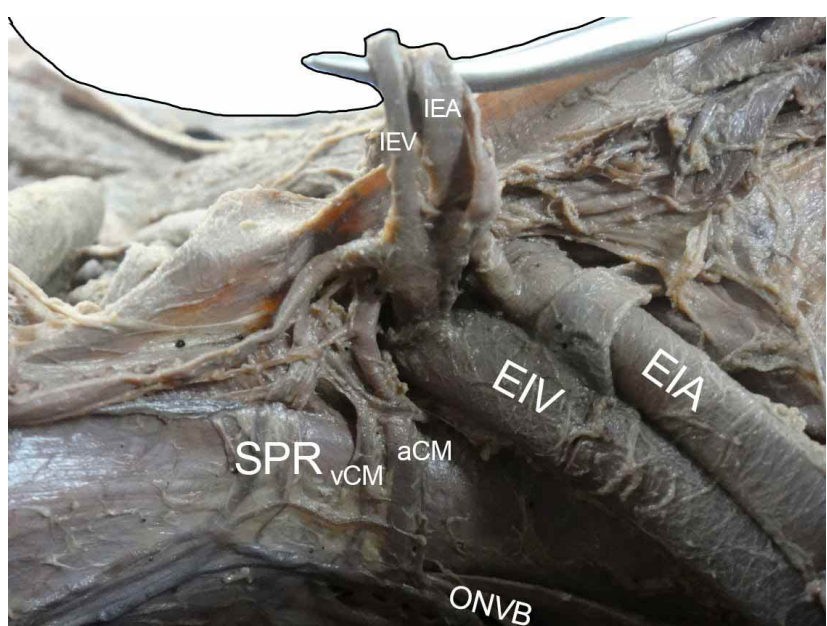

Fig. 1. Superior view of the right hemipelvis, the arterial and venous corona mortis can be seen ( $\mathrm{aCM}$ and $\mathrm{vCM}$, respectively). Legend: EIA = External iliac artery; EIV = External iliac vein; ONVB = Obturator neurovascular bundle; SPR = Superior pubic ramus; IEV $=$ Inferior epigastric vein; IEA = Inferior epigastric artery.

\section{DISCUSSION}

The common, external and internal iliac arteries are formed through a connection between the umbilical arteries and the fifth pair of lumbar intersegmental branches (pelvic plexus). This begins during the fifth week of embryonic development (Jusoh et al., 2010; Schoenwolf et al., 2014; Goke et al., 2016).

Branches of those vessels are formed as sprouts through a series of anastomotic channels, some of them enlarge, others diminish in size, thus, variations in the caliber, origin and trajectory of these branches are quite common (Jusoh et al.; Schoenwolf et al.; Goke et al.).

Variations of the OA and IEA are well described in the literature (Testut \& Latarjet, 1958; Sañudo et al., 2011; Al Talalwah; Goke et al.; Tubbs et al., 2016). CM incidence varies from $12 \%$ to $40 \%$ in most recent studies (Stavropoulou-Deli \& Anagnostopoulou; Pellegrino et al.; Baena et al.; Al Talalwah; Tajra et al.; Wada et al.).

Clinically, the CM can be easily ruptured in cases of acetabular and SPR fractures and cause severe hemorrhage. This is a concern, since incidence of low-energy osteoporotic pelvic fractures in the elderly are quite high (Henning et al., 2007; Ebraheim et al., 2008; Theodorides et al.; GarridoGomez et al.; Palacio \& Albareda).

$\mathrm{CM}$ rupture can result in life-threatening hypovolemic shock even though SPR fractures do not usually require surgical treatment. Patients with pubic ramus fracture include young people sustaining high-energy trauma such as motor vehicle accident or falls from height and elderly people after minor falls (Henning et al.; Theodorides et al.; GarridoGomez et al.; Palacio \& Albareda). Early signs of vascular injury are clinical hypoperfusion, lower abdominal mass in the abdomen (Chiu et al., 2009; Theodorides et al.).

Thus, the presence of a CM imposes threat and should not be overlooked in cases of these fractures.

Recent studies showed that the CM if one of the structures that the surgeon must observe during modified Stoppa approaches. Among other structures that should be identified are the external iliac artery and the superior gluteal neurovascular bundle (Bible et al., 2014).

Traditional, modified Stoppa, ilioinguinal and iliofemoral approaches are often used to treat acetabular and pelvic ring fractures, with a fairly good success rate (70-95 $\%$ ) and low rates of complications (Karunakar et al., 2004; Balbachevsky et al., 2006; Kacra et al., 2011; Bible et al.; Court-Brown et al., 2014; Jensen et al., 2015). Despite that, some studies showed vascular injury rates of $6.2 \%$ of patients with CM (Jensen et al.).

Ilioinguinal and iliofemoral approaches are related to higher risk of neurovascular bundle injuries, thus are becoming less and less preferred as a surgical treatment for fractures of the anterior region of the pelvis and acetabulum (Balbachevsky et al.; Yang et al.). Due to this, newer techniques such as minimally invasive ilioinguinal approach are being performed (Yang et al.).

Despite that, the ilioinguinal approach is still a good treatment choice in cases of anterior wall and column fractures, and two column fractures as well. The surgeon should access the medial window that is created by dissection of the iliopectineal fascia and retraction of the adjacent structures. This window exposes the anterior wall, the iliopectineal eminence and the quadrilateral surface, although before the vessels are retracted, the surgeon must carefully look for the CM (Karunakar et al.; Court-Brown et al.).

Modified Stoppa access have vantages such as smaller surgical incision and soft parts dissection and allows the surgeon to place the implant directly at the internal surface of the pelvis, thus, possessing less complication rates (Balbachevsky et al.).

In order to treat acetabular dysplasia, acetabular retroversion and other hips deformities, pelvic and acetabular osteotomies are usually the first choice of surgical treatment 
(De Kleuver et al., 1998; Wada et al.). Both are also good procedures to reduce symptoms and progression of hip osteoarthritis (Wada et al.).

Despite its good result rates, pelvic osteotomy is often associated with high complication rates (6-37\%). Studies suggested that major hemorrhage is an important complication and even though vascular injuries are uncommon, they are quite dangerous (Davey \& Santore; Brenøe et al., 2006; Wada et al.). The CM is in danger specifically during the medial approach. During other approaches for pelvic osteotomy the surgeon does not face the CM, as they are not exposed (De Kleuver et al.).

The medial approach seems technically easier to perform, although there is risk of CM injury and difficulty to get close to the hip joint. In addition, it does not seem to produce good results (De Kleuver et al.).

During ischial osteotomies, the OA and CM can be injured due to a difficulty of visualization during an anterior approach (Kamada et al., 2011; Wada et al.).

Different approaches of osteotomies possess different risks of iatrogenic injury since the structures involved are different. A recent study showed that the $\mathrm{OA}$ and $\mathrm{CM}$ are in greater danger in rotational acetabular osteotomy and pubic osteotomy than ischial osteotomy (Wada et al.).

Thus, knowledge of the incidence, size and anatomical relations of the $\mathrm{CM}$ is essential, especially to orthopedic surgeons, as osteotomies and Stoppa access are among the most performed orthopedic procedures. This knowledge is necessary in order to avoid complication rates due to iatrogenic rupture of this vessel.

Furthermore, the CM can be injured in pubic and acetabular fractures. Both types of trauma have a relatively high incidence among the elderly, hence, awareness of the $\mathrm{CM}$ is of great significance as to reduce delay in treatment of the hemorrhage.

BABINSKI, M. A.; GONÇALVES, C. P.; RAMALLO, D.; PIRES, L. A. S. \& FERNANDES, R. M. P. Implicaciones ortopédicas de la corona mortis: Reporte de un caso. Int. J. Morphol., 36(1):31-34, 2018.

RESUMEN: La corona mortis es clasificada como una conexión entre los vasos epigástricos inferiores y obturadores sobre la rama superior del pubis. Su incidencia varía según los diferentes estudios. La corona mortis es una variación anatómica extremadamente importante, ya que se es posible dañarla en un número significativo de procedimientos. Además, también puede re- sultar lesionada durante las fracturas pélvicas o acetabulares. Durante la disección de un cadáver de sexo masculino fijado en solución de formalina al $10 \%$, se observó la corona mortis arterial en el lado derecho de la región pélvica. El lado izquierdo de la pelvis no presentó ninguna variación. Se midió la corona mortis con ayuda de un calibre digital. Nuestro objetivo fue informar sobre esta variación y abordar - desde el punto de vista ortopédico - la importancia clínica y quirúrgica de la corona mortis.

PALABRAS CLAVE: Variaciones anatómicas; Corona mortis; Procedimientos ortopédicos; Acetábulo; Huesos pélvicos.

\section{REFERENCES}

Al Talalwah, W. A new concept and classification of corona mortis and its clinical significance. Chin. J. Traumatol., 19(5):251-4, 2016.

Baena, G.; Rojas, S. \& Peña, E. Corona mortis: Anatomical and clinical relevance and occurrence in a sample of the Colombian population. Int. J. Morphol., 33(1):130-6, 2015.

Balbachevsky, D.; Pires, R. E. S.; Faloppa, F. \& dos Reis, F. B. Treatment of pelvic and acetabular fractures through modified Stoppa port. Acta. Orthop. Bras., 14(4):190-2, 2006.

Bible, J. E.; Choxi, A. A.; Kadakia, R. J.; Evans, J. M. \& Mir, H. R. Quantification of bony pelvic exposure through the modified Stoppa approach. J. Orthop. Trauma, 28(6):320-3, 2014.

Brenøe, A. S.; Andersen, P. E. \& Overgaard, S. Endovascular embolisation of severe bleeding in connection with periacetabular osteotomy. Ugeskr. Laeger, 168(14):1453-4, 2006.

Chiu, Y.; Wong, T. C. \& Yeung, S. H. Haemodynamic instability secondary to minimally displaced pubic rami fractures: a report of two cases. $J$. Orthop. Surg. (Hong Kong), 17(1):100-2, 2009.

Court-Brown, C. M.; Heckman, J. D.; McKee, M.; McQueen, M. M.; Ricci, W. \& Tornetta III, P. (Eds.). Rockwood and Green's Fractures in Adults. $8^{\text {th }}$ ed. Philadelphia, Lippincott Williams \& Wilkins, 2014.

Davey, J. P. \& Santore, R. F. Complications of periacetabular osteotomy. Clin. Orthop. Relat. Res., (363):33-7, 1999.

de Kleuver, M.; Koojiman, M. A.; Kauer, J. M. \& Veth, R. P. Pelvic osteotomies: anatomic pitfalls at the pubic bone. A cadaver study. Arch. Orthop. Trauma. Surg., 117(4-5):270-2, 1998.

Ebraheim, N. A.; Liu, J.; Lee, A. H.; Patil, V.; Nazzal, M. M. S. \& Sanford, C. G. Obturator artery disruption associated with acetabular fracture: A case study and anatomy review. Inj. Extra, 39(2):44-6, 2008.

Garrido-Gómez, J.; Pena-Rodríguez, C.; Martín-Noguerol, T. \& HernándezCortes, P. Corona mortis artery avulsion due to a stable pubic ramus fracture. Orthopedics, 35(1):e80-2, 2012.

Goke, K.; Pires, L. A. S.; Leite, T. F. O. \& Chagas, C. A. A. Rare origin of the obturator artery from the external iliac artery with two obturator veins. J. Vasc. Bras., 15(3):250-3, 2016.

Henning, P.; Brenner, B.; Brunner, K. \& Zimmermann, H. Hemodynamic instability following an avulsion of the corona mortis artery secondary to a benign pubic ramus fracture. J. Trauma, 62(6):E14-7, 2007.

Jensen, K. O.; Sprengel, K.; Mica, L.; Somlyay, L.; Jentzsch, T. \& Werner, C. M. L. Surgical relevance of corona mortis and clinical outcome in pelvic trauma. Austin J. Anat., 2(2):1033, 2015.

Jusoh, A. R.; Abd Rahman, N.; Abd Latiff, A.; Othman, F.; Das, S.; Abd Ghafar, N.; Haji Suhaimi, F.; Hussan, F. \& Maatoq Sulaiman, I. The anomalous origin and branches of the obturator artery with its clinical implications. Rom. J. Morphol. Embryol., 51(1):163-6, 2010.

Kacra, B. K.; Arazi, M.; Cicekcibasi, A. E.; Büyükmumcu, M. \& Demirci, S. Modified medial Stoppa approach for acetabular fractures: an anatomic study. J. Trauma, 71(5):1340-4, 2011. 
Kamada, S.; Naito, M.; Shiramizu, K.; Nakamura, Y. \& Kinoshita, K. Is the obturator artery safe when performing ischial osteotomy during periacetabular osteotomy? Int. Orthop., 35(4):503-6, 2011.

Karunakar, M. A.; Le, T. T. \& Bosse, M. J. The modified ilioinguinal approach. J. Orthop. Trauma, 18(6):379-83, 2004

Palacio, J. \& Albareda, J. Severe haemorrhage secondary to an osteoporotic pelvic fracture: presentation of a case. Rev. Esp. Cir. Ortop. Traumatol., 58(3):192-5, 2014.

Pellegrino, A.; Damiani, G. R.; Marco, S.; Ciro, S.; Cofelice, V. \& Rosati, F. Corona mortis exposition during laparoscopic procedure for gynecological malignancies. Updates Surg., 66(1):65-8, 2014.

Sañudo, J. R.; Mirapeix, R.; Rodriguez-Niedenführ, M.; Maranillo, E.; Parkin, I. G. \& Vázquez, T. Obturator artery revisited. Int. Urogynecol. J., 22(10):1313-8, 2011.

Schoenwolf, G. C.; Bleyl, S. B.; Brauer, P. R. \& Francis-West, P. H. Larsen's Human Embryology. $5^{\text {th }}$ ed. Edinburgh, Churchill Livingstone, 2014

Stavropoulou-Deli, A. \& Anagnostopoulou, S. Corona mortis: anatomical data and clinical considerations. Aust. N. Z. J. Obstet. Gynaecol., 53(3):283-6, 2013.

Tajra, J. B. M.; Lima, C. F.; Pires, F. R.; Sales, L.; Junqueira, D. \& Mauro, E. Variability of the obturator artery with its surgical implications. $J$. Morphol. Sci., 33(2):96-8, 2016.

Testut, L. \& Latarjet, A. Tratado de Anatomía Humana. Barcelona, Salvat, 1958.

Theodorides, A. A.; Morgan, B. W. \& Simmons, D. Haemodynamic instability resulting from a low energy pubic ramus fracture in a 78year-old woman. A case report and review of the literature. Injury, 42(7):722-4, 2011.

Tubbs, R. S.; Shoja, M. M. \& Loukas, M., Eds. Bergman's Comprehensive Encyclopedia of Human Anatomic Variation: Hoboken, John Wiley \& Sons, 2016.

Wada, K.; Goto, T.; Tezuka, F.; Tamaki, S.; Hamada, D.; Tsutsui, T. \& Sairyo, K. Variations in the obturator artery around the obturator foramen assessed by three-dimensional computed tomographic angiography and prevention of vascular-related complications in rotational acetabular osteotomy. Int. Orthop., 41(1):133-9, 2017.

Yang, Y.; Li, Q.; Cui, H.; Hao, Z.; Wang, Y.; Liu, J.; Li, L. \& Zhou, D. Modified ilioinguinal approach to treat pelvic or acetabular fractures: A retrospective study. Medicine (Baltimore), 94(37):e1491, 2015.

\author{
Corresponding author: \\ Dr. Marcio Antonio Babinski \\ Morphology Department \\ Biomedical Institute - Fluminense Federal University \\ Av. Prof. Hernani Mello 101, CEP 24.210-150, Niterói \\ Rio de Janeiro \\ BRASIL
}

E-mail:mababinski@gmail.com

Received: 01-08-2017

Accepted: 14-11-2017 